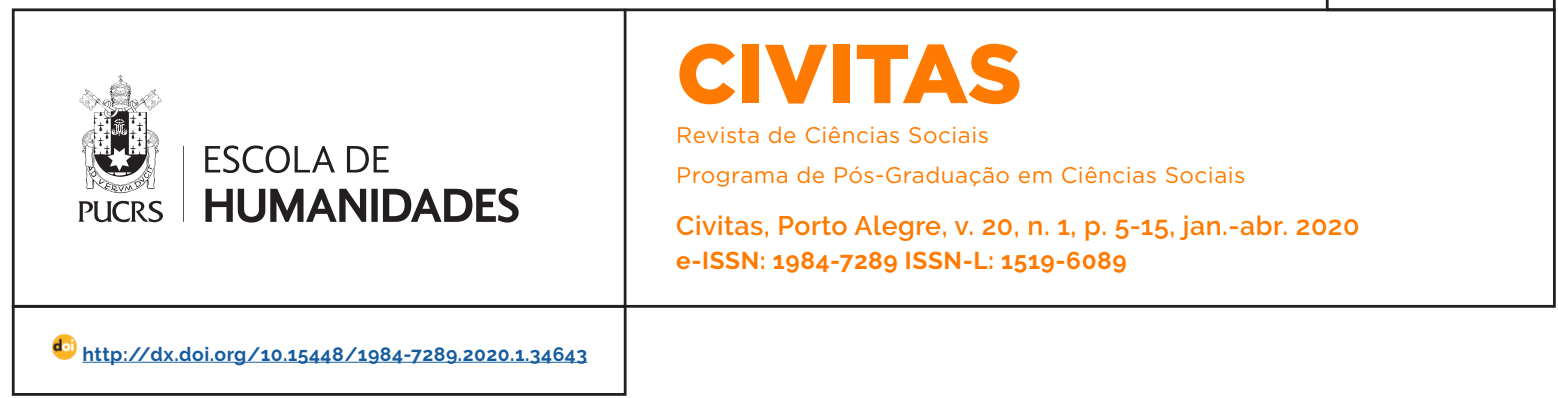

DOSSIÊ: OS NOVOS DESAFIOS DO DESENVOLVIMENTO NA REGIÃO AMAZÔNICA

\title{
Changing how we build hydropower infrastructure for the common good: lessons from the Brazilian Amazon
}

\author{
Mudando a maneira como construímos a infraestrutura hidrelétrica para o bem comum: \\ lições da Amazônia brasileira
}

Cambiar la forma en que construimos infraestructura hidroeléctrica para el bien común: lecciones de la Amazonia brasileña

Emilio Federico Moran ${ }^{1}$ orcid.org/0000-0001-5153-545X moranef@msu.edu

Recebido em: 12 set. 2019 Aprovado em: 13 nov. 2019 Publicado em: 25 mai. 2020
Abstract: Infrastructure projects like roads and hydroelectric dams are meant to help achieve national economic development goals in Brazil and the Amazon. In the case of hydropower dams, they have a very specific goal: that of producing energy from water sources. Unfortunately, that objective is frequently associated with environmental and social damages that result from the construction of dams. In the Amazon these damages are more serious in terms of the impacts on biological and cultural diversity. The research for this paper is based on 5 years of study by an interdisciplinary team using survey and ethnographic methods, both qualitative and quantitative. This history is repeated frequently, and it becomes necessary to ask what types of changes would be necessary to hydropower projects to begin to have social and environmental positive results. This paper explores the causes of the problems posed by dams and suggests solutions in the process of approval, construction and operation of hydropower dams that could lead to better outcomes for the common good of society.

Keywords: Hydropower. Dams. Social impacts assessment. Environmental impacts assessment. Deforestation. Resettlement.

Resumo: Projetos de infraestrutura como estradas e hidrelétricas são usados para o desenvolvimento econômico e nacional no Brasil e na Amazônia. As hidrelétricas, em particular, têm um foco na produção de energia de fontes hídricas. Infelizmente, frequentemente, esse objetivo está associado a danos ambientais e sociais que resultam da construção das barragens hidrelétricas. $\mathrm{Na}$ Amazônia tais danos são ainda mais sérios em termos dos impactos sobre a diversidade biológica e cultural. Esta pesquisa de cinco anos envolveu uma equipe interdisciplinar usando métodos de survey, etnográficos, qualitativos e quantitativos. Esta história se repete com frequência e torna-se necessário questionar quais alterações seriam necessárias para que projetos hidrelétricos possam gerar resultados mais positivos em termos ambientais e sociais. Este trabalho explora as causas dos problemas causados pelas hidrelétricas e sugere soluções de melhorias dos processos de aprovação, construção, e operação desses empreendimentos a fim de alcançar o bem comum da sociedade.

Palavras-chave: Hidrelétricas. Barragens. Avaliação de impactos sociais. Avaliação de impactos ambientais. Desmatamento. Reassentamento.

Resumen: Proyectos de infraestructura, como carreteras e hidroeléctricas, han sido usados para promover el desarrollo económico en Brasil y en la Amazonia. Las hidroeléctricas, en particular, se enfocan en la producción de energía a partir de fuentes hidricas. Desafortunadamente, estas se han asociado a daños sociales y ambientales que resultan de la construcción de represas. En la Amazonia, estos daños son más serios debido a la diversidad biológica y cultural de la región. Este estudio se basa en investigaciones llevadas a cabo a lo largo de cinco años por un equipo interdisciplinar que usó la encuesta social y la etnografia, ambos métodos tanto cuantitativa, como cualitativamente. Esta historia se repite con 
frecuencia con la construcción de represas y nos parece necesario preguntarnos qué tipo de cambios serian necesarios para que los proyectos de desarrollo de hidroeléctricas pudieran tener resultados sociales y ambientales positivos. Este trabajo explora las causas de los problemas asociados a la construcción de represas y sugiere soluciones desde el momento en que se aprueba su construcción, para el proceso de construcción de las mismas y para su operación, con el objetivo de que pudieran resultar en mejores condiciones para la sociedad.

Palabras claves: Hidroenergia, Represas. Evaluaciones de impacto social. Evaluaciones de impacto ambiental. Deflorestacion. Restablecimiento.

\section{Introduction}

Large infrastructure projects are promoted by the State to achieve regional and national goals. They are an example of how expenditures from the public coffers are invested in projects that are beyond the interest or capacity of the private sector, and which are justified because they are a public good that can enhance the lives, and income of citizens in a nation. National highways are a perfect example they link communities across a nation, bringing down the cost of transportation of goods and services to the benefit of producers and consumers. Another example are large-scale energy development projects. Among large infrastructure projects, developing countries are currently pursuing hydropower infrastructure construction to improve their position in the global economy and as an important component of their socio-economic development goals to produce food, generate energy, employment, and income; and improve the overall quality of life of their citizens (Tortajada, Altinbilek and Biswas 2012; Richter et al. 2010; Rosenberg et al. 1997). These worthy goals are clouded by negative social and environmental impacts associated with hydropower development (Moran et al. 2018), particularly largescale hydropower projects commonly thought of as those over $500 \mathrm{kw} / \mathrm{h}$ which makes one wonder whether hydropower projects follow the nation's lofty development goals. A recent study using a database of 220 dam-related conflicts found that in dams surrounded by controversies and conflict, the use of repression, criminalization, violent targeting of activists and assassinations were common (Del Bene, Arnim and Temper 2018). This is a result of a failure of the hydropower sector to address governance and sustainability issues. This paper, and a lot of the literature ${ }^{2}$ (e.g. WCD 2000), argues that they do not, and that we need to change business as usual in order to ensure that development takes place, that people affected by dams are better off as a result, and that people have priority in development.

Most of the developed world constructed large-scale hydroelectric dams up to the mid1970s. During this early era, the Tennessee Valley Authority (TVA) was viewed with admiration worldwide because of the positive regional economic development attributed to it. TVA was created in 1933 to serve portions of Tennessee, Alabama, Mississippi and Kentucky and it brought electrification to largely rural areas-- one of the first of its kind and widely imitated thereafter. It was given credit for attracting business and research to a vast area, and for controlling floods. It became a poster child for the hydropower industry as the way for government to assist in the modernization of agrarian societies. TVA consisted of 29 powerproducing hydropower facilities. TVA remains today as the largest public power utility in the USA and one of the largest producers of energy in the country - but hydropower constitutes only $9 \%$ of all the power it generates today (the rest being nuclear, coal, and gas). After 1975, a virtual stoppage of dam construction in the US and in Europe took place. The World Bank and Regional Development Banks ceased funding these projects. The reason for this change of heart was that the benefits of energy from hydropower did not outweigh the environmental and social costs associated with them. History, however. has a way of repeating itself.

After decades of neglect, organizations like the World Bank again have begun to provide support for large hydroelectric projects, this time in the Global South. World Bank funding increased from

\footnotetext{
2 World Commission on Dams-WCD. 2000. Dams and development: A new framework for decision-making. London: Earthscan. Accessed January 07, 2019. https://www.internationalrivers.org/sites/default/files/attached-files/world_commission_on_dams_final_report.pdf.
} 
1.6 million USD in 2000 to 6.2 million USD by 2009. "The world as a whole is generally coming to appreciate the fact that large water-infrastructure is essential for economic development as long as social and environmental issues are given appropriate consideration" (Tortajada, Altinbilek and Biswas 2012,9). The question today is not whether hydroelectric dams will be built, but how they can be built in a way that mitigates deleterious social and environmental consequences. Among developing countries, Brazil stands out as firmly committed to hydroelectric development and with China and Canada, are leaders in hydropower production. The question that must be asked is whether it has given appropriate consideration to social and environmental costs associated with this type of infrastructure development. Smaller hydropower projects, known in Brazil as $\mathrm{PCH}$, are more numerous and are thought of as having a lesser environmental and social impact, but because they are not subject to the same standards of environmental and social impact assessment, the jury is out as to whether they are better, or worse, in their consequences.

The development of hydropower in Brazil is a natural consequence of the richness of the potential for such energy production, and of a model of development that was ushered in by the military governments that ruled Brazil from 1964 to 1985 . This model was based on the notion of a Giant Brazil, capable of achieving top status among the world's economies, and for this to occur it had to have plenty of energy to power its economic development (Silva 1957). No government that followed has questioned this model of development nor the role of hydropower in this vision. This development model had several components: One was the development of energy sources, with hydropower as an obvious preferred choice, despite the experience in Europe and the USA with its social and environmental costs. Another was the occupation of the vast Amazon territory, which accounted for 54\% of Brazil's area. To undertake the latter, President Emilio Medici launched the First Program of National Integration (PIN) in 1970, which called for a massive effort at road-building, directed settlement, and geopolitical integration of the Amazon into national development goals (Moran 1975, 1981; Smith 1982). Through this first PIN, huge investments were made in building the Trans-Amazon Highway and the Cuiaba-Santarem Highway, opening up the region to settlers, developers, miners, ranchers, and urban commercial interests. Sleepy towns such as Altamira, Maraba and Itaituba were woken from their slumber, and they began to swell with population. First, the engineers and construction crews, then the wholesale and retail commercial sector arrived to provide for the swelling population coming to build the roads and then the many who came to settle in the region as farmers or service providers. Altamira went from slightly over 1,000 people in the urban area to over 10,000 in little over a year, reaching 85,000 by 1985 . As one might have expected, the influx of people surpassed the capacity of services to meet demand. After all, this project was viewed as the equivalent of putting a man on the moon, at the time, and there were no precedents on how to prepare for it. The small local hospital (Sesp) at the time could not keep up with the swelling population and the arrival of more medical personnel was slow in coming. Schools were built very fast but they too could not accommodate the swelling population. Classes were held in triple sections each day and it was still not enough. Teachers were recruited from all over the country with attractive double salary levels. Road accidents exploded in frequency, with road trauma the biggest source of morbidity for adults; followed by malaria (Moran 1975, 1976. 1981, 2016)

From 1976 to the present, the Amazon entered a steady process of deforestation and conversion of land from forest to pasture spearheaded by the opening up of the Amazon to development that has resulted in $20 \%$ of the region now being deforested and 90\% of deforested land being in pasture. It can be questioned whether this development strategy was successful, since cattle ranching creates few jobs. However, logging, cattle ranching and commodity production did increase the economic activities of the region 
and the small farm sector continues to this day despite the lack of support from the federal government. The opening of the region was led by smallholders and they did not disappear as land consolidation took place. Many smallholders who picked good soils have remained on their land all these years, some have expanded and are now small to medium size cattle ranchers, or cocoa farmers. Over the years, they built ever better homes, their children studied in the city, and many own homes in town while still continuing to manage their rural properties. In other words, over two generations, a not insignificant number of them moved from being landless to being middle class. Not all succeeded, however, as happens in all frontier regions. Over the past 40 years there has been land consolidation, as less capable farmers have sold their land and moved either to new frontiers or settled in the city to seek nonfarm employment. The local economy has grown and it has gone up and down with the price of major commodities, particularly, beef and cocoa. By 2010, the rural sector was stable and consolidating, the area was considered a productive region for beef and cocoa, and the city provided a haven for investment for rural people and opportunities for young people to get an education. A campus of the Federal University of Para had been built up in Altamira, and also one for the State University of Para, offering opportunities for local students.

\section{Belo Monte and hydropower infrastructure}

The Belo Monte dam was long in coming. It was part of the grand plan to ensure energy for Brazil's ambition to be a major world power (Silva 1957). Rich in rivers, Brazil has always looked to hydropower as a way to meet this ambition. Around 100 dams were built in the 1950's, 103 in the 1960's, 151 in the 1970's and 1980's (Khagram 2004, 142 apud Fuchs 2015). We can look back to the military government and its development model for the origins of Belo
Monte and other hydropower projects. The stateowned Eletrobrás, and its North Region subsidiary, Eletronorte, began to propose a series of dams: one or more on the Xingu; Balbina near Manaus and Rôndonia; Tucurui on the Tocantins. Some were built like the Tucurui and Balbina, while others were postponed for decades, like Belo Monte. ${ }^{3}$

Roads were built to connect the Amazon to the rest of the country and to guarantee its borders, whereas dams are built to ensure that there is power for the industrial development of the country as a whole. It also provides the foundations for an urban Brazil, one that transitioned from a rural-based to an urban-industrial economy. That process of hydropower development was fully realized decades ago in the south and southeast, and it is now unfolding in the Amazon. The industries that first entered the Amazon were energy-intensive minerals: gold, iron, aluminum and copper. Tucurui provided the initial energy to support Carajás, and then the bauxite mining areas at Barcarena. The Xingu from the 1970's was of interest to the electric sector. An inventory of the hydroelectric potential of the Xingu Basin was produced in 1979 in which the optimal exploitation was said to be five dams on this river and one in its affluent, the Iriri river (Netto et al. 2007 apud Fuchs 2015). Estimations showed that, together, they could generate 20 GW of energy, half of the capacity of all other hydroelectric projects in Brazil at that time. These preliminary studies did not consider the impact on indigenous areas even though some indigenous areas, and environmentally sensitive areas would go underwater. The Constitution of 1988 began to change the receptiveness of people to dams by giving indigenous people rights that they did not have before. It made explicit that traditional and indigenous people had rights to their lands even if they were not titled because of traditional use rights. The constitution is frequently invoked, especially by indigenous people, in their struggle to stop dams from being built on their territories,

3 Conservation Strategy Fund. 2006. Custos e benefícios do Complexo Hidrelétrico Belo Monte: uma abordagem econômico-ambiental. Washington DC: Conservation Strategy Fund Report. Accessed July 22, 2019. https://www.conservation-strategy.org/sites/default/ files/field-file/4_Belo_Monte_Dam_Report_mar2006.pdf: 
or if they might affect their traditional livelihoods. Most recently, the constitution was invoked by the Munduruku indigenous groups on the Tapajos Basin to stop a set of dams planned for that region, and their demands have held up in court up to 2019 .

In fact, indigenous people have been learning from past dam projects how to be more effective. The lessons from Tucurui and Balbina were important in seeing that there was a recurrent lack of transparency in the process of consultation; that displacement of people led to impoverishment outcomes rather than improvements in livelihoods as promised; and that flooded areas were always larger than were estimated (Fearnside 1989, 1999). Tucurui flooded 2,430 square kilometers with 36\% of that area being the indigenous territories of the Parakana. In Balbina, the Waimi-Atroari were displaced and villages were forced to move (Viveiros de Castro et al. 1988 apud Fuchs 2015). The numerous problems in Belo Monte, observed by Munduruku leaders first-hand, inspired their legal actions to invoke the Constitution as a way to stop the planned dams from going forward (Moran 2016).

In the first decade of the 21st century, Eletronorte developed what became a new strategy to build Belo Monte: selling a concern with blackouts nationwide such as those that took place in 2001 and the need to build more hydropower dams to avoid a recurrence; moving the dam to the Volta Grande of the Xingu near Altamira to address concerns from indigenous people; and using the run-of-river technology designed to operate using the flow of the river itself to power the turbines and reducing the size of the reservoir which addressed the concerns of environmentalists with the loss of land and biodiversity. These changes and a political decision by the government to engage in a nationwide effort at infrastructure construction (PAC or Programa de Aceleração do Crescimento) to try and ride out the worldwide recession of 2008 were cited as drivers of the decision to build Belo Monte. As usual the creation of jobs under the PAC was cited as a strong motivation, in addition to the regional economic development that was promised would take place with the production of $11 \mathrm{GW}$ of energy from Belo Monte.

In 2010 the Workers' Party (PT) government gave clearance to start Belo Monte and selected Norte Energia, a consortium of firms, to undertake construction and then to run the dam for the next 35 years (Fuchs 2015). Construction began in 2011 and despite decades of discussion about the dam, the municipal government and the private sector seemed unprepared for the rapid changes that took place. Altamira went from 85,000 to an estimated 150,000 in less than four years. This led to rents, real estate, food, and most commercial goods and service skyrocketing in price. Wages went up, doubling in just two years, and attracted labor from both rural and urban sectors. But no additional funds were released by the federal or state government to help the municipality cope with these rapid changes. Thus, there was no additional policemen, no additional garbage pickup trucks, no water and sanitation infrastructure to accommodate this rapid grown in population.

The authorities at all levels were "unprepared" for the arrival of this doubling of population for what was an even larger infrastructure project than the Trans-Amazon highway and all services - medical, educational, roads, police, and health - found themselves unable to meet the explosive growth and the ensuing chaos that resulted. Sanitation got so bad that for a while Altamira was dubbed in Brazil's newspapers as "the city of the urubus," birds of carrion that could be seen everywhere eating the uncollected trash. Dengue spiked and whole neighborhoods were stricken with this debilitating illness. Altamira city, that in the late 70's and early 80's had been fully paved by a mayor with a progressive agenda and with schools and hospitals sufficient to meet its normal needs, returned to being a city full of potholes that ruined vehicles, and to cycles of either mud or dust which characterized the early 70's when Altamira was first transformed by the arrival of the Trans-Amazon Highway builders and settlers. Criminality spiked with the swelling of population, and no additional police were added to help contain it. Drugs and prostitution became commonplace, and during the peak of 
construction Altamira became the most violent city in Brazil per capita.

Communities affected by dams have frequently complained about the lack of consultation and attention to known negative impacts on society and environment, as well as the questionable promises made by the energy sector (cheaper energy bills, more jobs). In Belo Monte, Santo Antonio, and Jirau (these latter two on the Madeira river) the electric bills of people went up rather than down, and the jobs promised to locals went mostly to outsiders and disappeared within 5 years. Belo Monte was a missed opportunitythe promise of jobs ephemeral, water and sanitation for all unrealized, the regional economic development unachieved, and the city much less safe and livable than before (Calvi 2019).

Much of the debate over Belo Monte, and other Amazonian dams, centers on the priority given to the industrial exploitation of minerals, and of energy that will benefit other parts of Brazil more than those directly affected by it (Fearnside 1999; Égré et al. 2003). What has been less a focus of attention is the unpreparedness of municipal, state and federal agencies to take the necessary steps to reduce the negative social impacts of large-scale infrastructure projects such as Belo Monte and the lack of compliance of Brazil with the recommendations made by the World Commission on Dams (WCD) in 2000. The latter had a set of case studies (that included the Tucurui dams in the Amazon) and detailed recommendations for reducing the social and environmental impacts of hydropower dams. Brazil and the Energy Agencies like Eletrobrás and Aneel refused to endorse these recommendations. One must ask the question: why? The recommendations were numerous but sensible products from worldwide experiences: an emphasis on timely consultation with people likely to be affected by the dam and giving people the opportunity oppose and stop a dam; ensuring that people are better off economically than before the dam was built; making the environmental impact assessments and its findings part of the decisionmaking of whether the dams are built; and so on. It is well-known that once a dam is approved the engineering firms in charge of building it move very fast because it is in their interest to use the equipment on a 24-hour basis, rotate work crews through just such a daily schedule, and then move to the next large project. They even have built-in incentives to finish ahead of schedule. Not so for the government agencies in charge of building hospitals, schools, health posts, and local roads. They have unclear boundaries as to what each level of governance is responsible for, or they have overlapping responsibilities, which is even more of a problem. They are reluctant to use their budgets (which rarely would have foreseen the eventuality of a major dam coming), but postpone taking action because they hope that the construction company will pay for some or all of these additional costs, and the federal government claims it is unable to allocate additional funds for the increase in population because the basis for the allocations is the decadal census-and in the case of Belo Monte the census happened in 2010, months before the dam building was announced, and within months the data was no longer relevant due to the explosive growth in population. The lack of official figures for population resulted in unwillingness by government at all levels in providing emergency funding to meet these urgent needs, hiding behind the cover that they have no official census information to base decisions on how much funding to provide. Just how should government decision-makers go about making these important policy decisions?

\section{Changing how we build infrastructure}

One of the clear needs that must be addressed to reduce negative impacts on the population affected by a large infrastructure project, is to rethink the chronology of a planned dam. First comes the planning of whether to build it, which implies an examination of costs and benefits, whether the people affected favor or oppose the infrastructure and its impact on their lives. This presumes an intense and honest consultation with the local population, which is mandated by article 169 of the ILO, the International Labor 
Organization, with regards traditional and indigenous populations - but that should be applied to any citizen even remotely affected by the proposed infrastructure. This demand is also supported by the Brazilian Constitution of 1988 and by the recommendations of the World Commission on Dams. ${ }^{4}$ Unfortunately, to date many of these consultations are more proforma than honestly held, with engineers presenting what they are going to do, often in technical language, and allowing very little opportunity for people to express their views.

Several things are needed to ensure benefits to the population from dam construction:

1. Environmental Impact Assessments (EIAs) and Social Impact Assessments (SIAs) need to have teeth, such as being capable of stopping a dam. They should be carried out with sufficient lead-time to provide a credible assessment and have built-in capacity to stop the building of a dam if needed protections to biodiversity and human populations are not in place. EIAs and SIAs must be carried out by firms serving citizens rather than the dam builders. EIAs and SIAs should not be carried out by subsidiaries of the firms engaged in building the dam. They function more as promoters of the dam than as evaluators of whether the dam should be built by assessing the real Free and informed consultation costs. Benefits are routinely inflated, and costs are minimized in current EIAs and $\mathrm{SIAs}^{5}$ (Doria et al. 2018).

2. Public hearings and sufficient social engagement addressing the consequences from the dam has to be allowed before final approval is given. Compliance with article 169 of the ILO, requiring previous and free consultation with indigenous and traditional populations should be expected, in a manner that allows full discussion of the pros and cons, without underestimating costs, and inflating benefits to those affected.
3. Government preparation and budgeting for the Expected Impacts. Consultation should be planned to be of at least two years in advance of construction and should engage federal, state and municipal actors in determining what preparations need to be provided in advance of the construction to meet the needs of people and the environment. That means accords over the provisioning for police, water and sanitation, hospitals and health posts, schools, and other basic infrastructure.

4. At present, most devices ("ladders") to help migrating species get across dammed areas do not work or are not even put in place. Targets for fish passage are being missed by several orders of magnitude - even in the best of cases only 3\% make it (Brown et al. 2013); the authors of this study make a case to admit failure of these ladders and propose dam removal in cases where fish passages are not working. They propose a cautionary tale for developing countries' current efforts, arguing that fish passages do not compensate for the damage to the fisheries since they generally do not work. Prioritizing energy production at the expense of the fish biodiversity and abundance in the rivers needs to stop.

5. There is a lack of planning that considers the impacts of dams in a manner that ensures connectivity of the ecosystems (Finer et al. 2012; Forsberg et al. 2017)hydropower projects are rapidly increasing in the Neotropics. This is especially true in the wet and rugged Andean Amazon, where regional governments are prioritizing new hydroelectric dams as the centerpiece of long-term energy plans. However, the current planning for hydropower lacks adequate regional and basin-scale assessment of potential ecological impacts. This lack of strategic planning is particularly problematic given the intimate link between the Andes

\footnotetext{
4 World Commission on Dams-WCD. 2000. Dams and development: A new framework for decision-making. London: Earthscan. Accessed January 07, 2019. https://www.internationalrivers.org/sites/default/files/attached-files/world_commission_on_dams_final_report.pdf.

5 World Commission on Dams-WCD. 2000. Dams and development: A new framework for decision-making. London: Earthscan. Accessed January 07, 2019. https://www.internationalrivers.org/sites/default/files/attached-files/world_commission_on_dams_final_report.pdf.
} 
and Amazonian flood plain, together one of the most species rich zones on Earth. We examined the potential ecological impacts, in terms of river connectivity and forest loss, of the planned proliferation of hydroelectric dams across all Andean tributaries of the Amazon River. Considering data on the full portfolios of existing and planned dams, along with data on roads and transmission line systems, we developed a new conceptual framework to estimate the relative impacts of all planned dams. There are plans for 151 new dams greater than 2 MW over the next 20 years, more than a 300\% increase. These dams would include five of the six major Andean tributaries of the Amazon. Our ecological impact analysis classified $47 \%$ of the potential new dams as high impact and just $19 \%$ as low impact. Sixty percent of the dams would cause the first major break in connectivity between protected Andean headwaters and the lowland Amazon. More than 80\% would drive deforestation due to new roads, transmission lines, or inundation. We conclude with a discussion of three major policy implications of these findings. 1. The goal needs to be to incorporate community concerns and to design new dams in ways that they can improve livelihoods by increasing crop productivity, maintain fisheries yields, increase food security, and improve access to water and energy from the project.

6. Follow the WCD recommendations and a rigorous cost/benefit analysis would have resulted in Belo Monte not being built. An analysis showed that there was a $72 \%$ chance that the costs of Belo Monte would be greater than the benefits (Souza Junior et al. 2010), something that has proven correct. By the guidelines set out by Scudder (2005). an experienced scholar of dams and resettlement across the world, many or even most large dams should not have been built. Those guidelines, and those of other bodies such as the WCD, agree on much of what is wrong with the current rush to build large dams, and the apparent difficulty in meeting those minimal guidelines. To date, Brazil has refused to follow these guidelines.

7. Need for New Tools. The Amazon Cooperation Treaty Organization and the Water Management Law (law 9433/1997), which promote integrated water management could begin to change how decisions are made. An international panel of experts could use existing knowledge to determine vulnerabilities using tools such as the Dam Environmental Vulnerability Index (Latrubesse et al. 2017) at the sub-basin scale. These tools, and an engaged civil society and other stakeholders could more accurately consider the environmental and social costs of a proposed dam.

\section{Are small dams an alternative?}

The energy sector in countries like Brazil and India has recently promoted and begun constructing small dams or $\mathrm{PCH}$ s as a more benign technology than large dams, yet there is very little evidence for this claim. The U.S. has a long history of building low-head or small dams (2 million of them); however, Fencl et al. (2015)000,000 lowhead dams ( $<7.6 \mathrm{~m}$ high note that the claim of their minimal impact is largely untested. By virtue of their abundance, small dams can substantially impact flowing aquatic ecosystems (Premalatha et al 2014). Small hydro dams possess the same characteristics as large dams, with the only difference being their size. China and India are the current leaders in small hydro dams, and Brazil aspires to catch up. Their power generation benefits, particularly in isolated mountainous terrain, cannot be dismissed. Their ecological, hydrological and social impacts should be scrutinized just like large dams. In Brazil, as well as most countries, small dams currently bypass environmental and social impact assessments, which explains their popularity with the hydropower sector. Further, in recent energy auctions, windpower has shown it can produce more energy per kwh more cheaply than $\mathrm{PCH}$. Windpower is growing rapidly in Brazil now that it has shown its efficiency, and PCHs should be slowed down or stopped until they can 
show that they meet environmental assessment standards for low impact.

\section{Conclusions}

The hydropower industry needs to be subjected to evaluation measures that can stand public scrutiny. Many of these have been proposed but are rarely implemented. As mentioned above, the recommendations of the WCD report ${ }^{6}$ provided sensible guidelines for social and environmental sustainability for hydropower projects. Since 2001, the WCD guidelines have influenced international accords, financial safeguards, and national laws. For example, the WCD recognized the importance of a full evaluation of energy options to meet energy mix needs, before putting a hydropower project on paper. The WCD also promotes alternative siting scenarios for dams that are already assumed will be approved. Too frequently, energy and water planning is secretively guarded by governments, sometimes in collusion with dam builders, is closed to the participation of civil society, and does not follow the WCD guidelines. For hydropower planning to change, government and industry must prioritize transparency, by inviting civil society to the table to discuss and agree on what a country's energy matrix should look like. A growing chorus of scholars across fields of science are calling for modular solutions that combine wind, solar and hydropower to provide alternative energy sources that are environmentally, socially, and financially desirable (Latrubesse et al. 2017; Fillizola et al. 2015: Pereira et al. 2012).

Once it is decided to build large infrastructure, and we have suggested that in some cases they should not be built because they fail to demonstrate that benefits outweigh costs, the various levels of government need to go into emergency mode for a year or two and reallocate funds to build the basic services for what we know will occur: more population requires more hospitals, schools, improved roads, sanitation, and policing in advance of the arrival of the population increase. An increase in population as is expected with a large dam results in a boom economy that affects rents and real estate prices, prices of food, and increased criminality. That means that additional police need to be trained and be put in place in advance of the arrival of the construction crews and the many others who come in hope of being hired. Many of them do not have the skills to be hired and become a population that will turn to criminal activity to make a living. For a couple of years Altamira became the most violent city in Brazil on a per capita basis. Schools and teachers need to be put in place to keep children in school and avoid vagrancy, drug use and criminal behavior. Additional health services capacity needs to be provided, including attention to areas often neglected such as sewage, and sexuallytransmitted diseases or STDs. The minimum frame to have these facilities in place is two years, if emergency mode is undertaken that permits the use of educated projections, and budget reallocations for this short period independent of the inevitably outdated census data collected only every ten years. Without this type of rethinking on how projects are implemented, we will continue to decry the human suffering and nothing will change. We have abundant evidence of what is wrong with how hydropower projects are designed and implemented, what is missing is political will to implement the sensible recommendations of the ILO, WCD, and the Brazilian Constitution, and to put people, rather than energy production, as the first priority.

\section{Acknowledgements}

The author wishes to thank the National Science Foundation (grant 1639115) and the Fundação de Amparo à Pesquisa do Estado de São Paulo (grant 2012/51465-0) that provided support for this research. None of these agencies should be held responsible for the findings and results presented herein as they are the sole responsibility of the authors.

\footnotetext{
6 World Commission on Dams-WCD. 2000. Dams and development: A new framework for decision-making. London: Earthscan. Accessed January 07, 2019. https://www.internationalrivers.org/sites/default/files/attached-files/world_commission_on_dams_final_report.pdf.
} 


\section{References}

Brown, Jed J., Karin E. Limburg, John R. Waldman, Kurt Stephenson, Edward P. Glenn, Francis Juanes and Adrian Jordaan. 2013. Fish and hydropower on the U.S. Atlantic Coast: failed fisheries policies from half-way technologies. Conservation Letters 6: 280-286. https:// doi.org/10.1111/conl.12000.

Calvi, Miqueias Freitas. 2019. (Re)organização produtiva e mudanças na paisagem sob influência da hidrelétrica de Belo Monte. Tese de doutorado, Unicamp, Campinas.

Del Bene, Daniela, Arnim Scheide and Leah Temper. 2018. More dams, more violence? A global analysis of resistance and repression around conflictive dams through co-produced knowledge. Sustainability Science 13, n. 3: 617-633. https://doi.org/10.1007/s11625-018-0558-1.

Doria, Carolina Rodrigues da Costa, Simone Athayde, Elineide E. Marques, Maria Alice Leite Lima, Jynessa Dutka-Gianelli, Mauro Luis Ruffino, David Kaplan, Carlos E. C. Freitas and Victoria N. Isaac. 2018. The invisibility of fisheries in the process of hydropower development across the Amazon. Ambio 47, n. 4: 453-465. https:// dx.doi.org/10.1007\%2Fs13280-017-0994-7.

Égré, Dominique and Pierre Senécal. 2003. Social impact assessments of large dams throughout the world: lessons learned over two decades. Impact Assessment and Project Appraisal 21, n. 3: 215-224. https://doi. org/10.3152/147154603781766310.

Fencl, Jane S., Martha E. Mather, Katie H. Costigan and Melinda D. Daniels. 2015. How big of an effect do small dams have? Using geomorphological footprints to quantify spatial impact of low-head dams and identify patterns of across-dam variation. PLoS One 10, n. 11: 1-22. https://doi.org/10.1371/journal.pone.0141210.

Fearnside, Philip M. 1989. Brazil's Balbina Dam: environment versus the legacy of the pharaohs in Amazonia. Environmental Management 13, n. 4: 402-423. https:// doi.org/10.1007/BF01867675.

Fearnside, Philip M. 1999. Social Impacts of Brazil's Tucurui Dam. Environmental Management 24, n. 4: 483-95. https://doi.org/10.1007/s002679900248.

Filizola, Naziano, Edileuza Melo, Elisa Armijos and John Mcglynn. 2015. Preliminary analysis of potential for river hydrokinetic energy technologies in the Amazon basin. Infrastructure and enviroment departament. Energy Division. Technical note n. IDB - TN - 891. https://doi. org/10.18235/0000222.

Finer, Matt and Clinton N. Jenkins. 2012. Proliferation of hydroelectric dams in the Andean amazon and implications for andes-amazon connectivity. PLoS One 7. n. 4: 1-9. https://doi.org/10.1371/journal.pone.0035126.

Forsberg, Bruce R., John M. Melack, Thomas Dunne, Ronaldo B. Barthem, Michael Goulding, Rodrigo C. D. Paiva, Mino V. Sorribas, Urbano L. Silva Jr. and Sabine Weisser. 2017. The potential impact of new Andean dams on Amazon fluvial ecosystems. PLoS One 12, n. 8: 1-35. https://doi.org/10.1371/journal.pone.0182254.
Fuchs, Vanessa B.2015. Breaking the walls down: the practice of prior, free and informed consultation between colonial designs and a new environmental governance framework in Brazil (the Belo Monte case). PhD Dissertation, IHEID - Institut d'Études Internationales et du Développement, Geneva.

Khagram, Sanjeev. 2004. Dams and development: transnational struggles for water and power. Ithaca: Cornell Univ. Press. https://doi.org/10.1162/1526380054794853

Latrubesse, Edgardo. M., Thomas Dunne, Eugenio Y. Arima and Edward Park. 2017. Damming the rivers of the Amazon basin. Nature 546, n. 7658: 363-369. https:// doi.org/10.1038/nature22333.

Moran, Emilio F. 1975. Pioneer farmers of the transamazon highway: adaptation and agricultural production in the lowland tropics. PhD Dissertation, U F - University of Florida.

Moran, Emilio F. 1976. Agricultural development along the transamazon highway. Bloomington: Center for Latin American Studies Working Papers.

Moran, Emilio F. 1981. Developing the Amazon. Bloomington: Indiana University Press.

Moran, Emilio F. 2016. Roads and dams: infrastructure-driven transformations in the Brazilian Amazon. Ambiente e Sociedade 9, n. 2: 207-220. https://doi. org/10.1590/1809-4422ASOC256V1922016.

Moran, Emilio. F., Maria C. Lopez, Nathan Moore, Norbert Müller and David W. Hyndman. 2018. Sustainable hydropower in the $21^{\text {st }}$ century. Proceedings of the National Academy of Sciences of the United States of America (PNAS) 115, n. 47. https://doi.org/10.1073/ pnas.1809426115.

Netto, Carlos Alberto Moya Figueira, Hélio Costa de Barros Franco e Paulo Fernando Souto Rezende. 2007. AHE Belo Monte - evolução dos estudos. Anais do XXVII Seminário Nacional de Grandes Barragens. Belém, Brasil: Comitê brasileiro de barragens.

Pereira, Márcio, Cristiane F. Camacho, Marcos A. V. Freitas and Neilton Silva. 2012. The renewable energy market in Brazil: current status and potential. Renewable Sustainable Energy Reviews 16, n. 6: 3786-3802. https:// doi.org/10.1016/j.rser.2012.03.024.

Premalatha, M, Tabassum Abbasi, Tasneem Abbasi and S. A. Abbasi. 2014. A critical view on the eco-friendliness of small hydroelectric installations. Sci Total Environ 481, n. 1: 638-643. https://doi.org/10.1016/j. scitotenv.2013.11.047.

Richter, Brain D., Sandra Postel, Carmen Revenga, Thayer Scudder, Bernhard Lehner, Allegra Churchill and Morgan Chow.2010. Lost in Development's shadow: the downstream human consequences of dams. Water Alternatives 3 (2): 14-42. Accessed on: July 23. 2019. http://Www.water-alternatives.org/index.php/ volume3/v3issue2/80-a3-2-3/file.

Rosenberg, D. M., F. Berkes, R. A. Bodaly, R. E. Hecky, C A. Kelly and J. W. M. Rudd. 1997. Large-scale impacts of hydroelectric development. Environmental Reviews 5. n. 1: 27-54. https://doi.org/10.1139/a97-001. 
Scudder, Thayer. 2005. The future of large dams: dealing with social, environmental, institutional and political costs. London: Earthscan. https://doi. org/10.4324/9781849773904

Silva, Golbery do Couto e. 1957. Aspectos geopolíticos do Brasil. Rio de Janeiro: Biblioteca do Exército.

Sousa Júnior. Walter C. and John Reid. 2010. Uncertainties in Amazon hydropower development: risk scenarios and environmental issues around the Belo Monte dam. Water Alternatives 3, n. 2: 249-268.

Smith, Nigel J. H. Rainforest corridors. 1982. Berkeley: University of California Press.

Tortajada, Cecilia, Dogan Altinbilek and Asit K. Biswas, eds. 2012. Impacts of large dams: a global assessment. Dordrecht: Springer.

Viveiros de Castro, Eduardo e Lúcia M. M. de Andrade. Hidrelétricas do Xingu: o estado contra as sociedades indígenas. 1998. In As hidrelétricas do Xingu e os povos indigenas, organizado por Lúcia M. M. de Andrade e Leinad Ayer Santos, 7-23. São Paulo: Comissão Pró-Índio de São Paulo. https://doi.org/10.1590/s0104$\underline{12902007000200019}$

\section{Emilio Federico Moran}

John A. Hannah Distinguished Professor, Center for Global Change and Earth Observations and Dept. of Geography, Michigan State University (MSU), East Lansing, MI, USA. 